\title{
ChemComm
}

\section{Cyclopentadiene-mediated hydride transfer from rhodium complexes $\dagger$}

Cite this: Chem. Commun., 2016 52, 9105

\author{
C. L. Pitman, O. N. L. Finster and A. J. M. Miller*
}

Received 20th January 2016,

Accepted 29th February 2016

DOI: $10.1039 / c 6 c c 00575 f$

www.rsc.org/chemcomm

\begin{abstract}
Attempts to generate a proposed rhodium hydride catalytic intermediate instead resulted in isolation of $\left(\mathrm{Cp}{ }^{*} \mathrm{H}\right) \mathrm{Rh}(\mathrm{bpy}) \mathrm{Cl}(1)$, a pentamethylcyclopentadiene complex, formed by $\mathrm{C}-\mathrm{H}$ bond-forming reductive elimination from the fleeting rhodium hydride. The hydride transfer ability of diene 1 was explored through thermochemistry and hydride transfer reactions, including the reduction of $\mathrm{NAD}^{+}$.
\end{abstract}

Transition metal catalysts capable of selective hydride transfer to the enzyme cofactor nicotinamide adenine dinucleotide $\left(\mathrm{NAD}^{+}\right)$to form the 1,4-reduced product $(1,4-\mathrm{NADH})$ are critical links between organometallic and enzymatic catalysis in emerging strategies in sustainable, enantioselective organic synthesis. ${ }^{1}$ Biocompatible catalytic routes for 1,4-NADH regeneration provide access to enzymatic hydride transfer reactivity without stoichiometric amounts of the complex molecule 1,4-NADH. ${ }^{2}$ Of the organometallic catalysts that have been shown to regenerate $\mathrm{NADH}$, rhodium complexes have emerged as selective and efficient catalysts for reduction at the 4-position of nicotinamides, spurring innovation in tandem bio-organometallic catalysis (Scheme 1). ${ }^{1 b}$

In the presence of a precatalyst like $\left[\mathrm{Cp}{ }^{*} \mathrm{Rh}(\mathrm{bpy})\left(\mathrm{OH}_{2}\right)\right]^{2+}\left(2 ; \mathrm{Cp}^{*}\right.$ is pentamethylcyclopentadienyl and bpy is $2,2^{\prime}$-bipyridine), generation of 1,4-NADH can be accomplished using chemical reductants (e.g. formate) or by electrochemical methods (by $\left.1 \mathrm{H}^{+} / 2 \mathrm{e}^{-}\right)$. The mechanism is typically proposed to proceed via $\left[\mathrm{Cp}^{*} \mathrm{Rh}(\mathrm{bpy})(\mathrm{H})\right]^{+}(3)$ with selectivity directed by coordination of $\mathrm{NAD}^{+}$to the Rh centre after an $\eta^{5}$ - to $\eta^{3}-\mathrm{Cp}^{*}$ ring slip. ${ }^{3}$ Drawing on this mechanism, $\mathrm{Cp}^{*} \mathrm{Rh}(\mathrm{bpy})$-based catalysts have been applied in ketone and aldehyde reductions ${ }^{4}$ and hydrogen evolution. ${ }^{5}$

After considering the hydricity, or hydride donor ability, of the iridium analogues $\left[\mathrm{Cp}^{*} \operatorname{Ir}(\mathrm{bpy})(\mathrm{H})\right]^{+}{ }^{6}$, we were interested in the comparison to rhodium hydride 3 . Relatively few hydricity values have been determined in water, and these Rh complexes provided an opportunity to learn more about an important

Department of Chemistry, University of North Carolina at Chapel Hill, Chapel Hill, NC 27599-3290, USA. E-mail: ajmm@email.unc.edu

$\dagger$ Electronic supplementary information (ESI) available: NMR and UV-vis spectra. Hydricity determination and DFT details. CCDC 1447440 (1). For ESI and crystallographic data in CIF or other electronic format see DOI: 10.1039/c6cc00575f

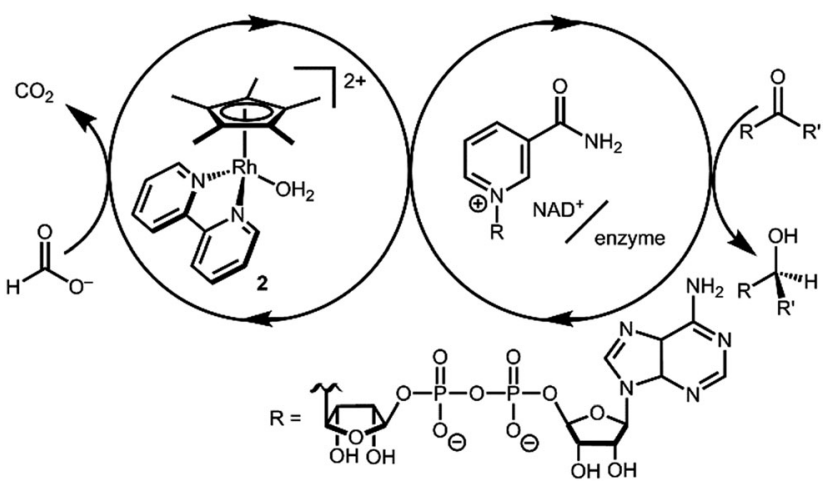

Scheme 1 Tandem catalytic cycle for Rh, NAD ${ }^{+}$, and enzyme mediated reductions.

catalytic intermediate and add new data to the emerging area of aqueous hydricity. $^{7}$

In order to determine the hydricity of $\mathbf{3}$, we first needed a preparative route for this proposed-but not previously isolated-intermediate. Reduction of $\left[\mathrm{Cp}^{*} \mathrm{Rh}(\mathrm{bpy})(\mathrm{Cl})\right][\mathrm{Cl}](4)$ in a pH 5 formate solution (following a procedure that cleanly generates the $\operatorname{Ir}$ analogue $\left.\left[\mathrm{Cp}^{*} \operatorname{Ir}(\mathrm{bpy})(\mathrm{H})\right]\left[\mathrm{PF}_{6}\right]\right)^{8}$ produced a dark red solution from which a green solid precipitated on addition of $\left[\mathrm{NH}_{4}\right]\left[\mathrm{PF}_{6}\right]$. Dissolution of the solids in $\mathrm{CD}_{3} \mathrm{CN}$ cleanly produced a red solution containing a new species. Surprisingly, the $\mathrm{Cp}^{*}$ methyl resonances were inequivalent: two singlets $(6 \mathrm{H}$ integration each) and a doublet $(J=6.2 \mathrm{~Hz}, 3 \mathrm{H})$ were present in the aliphatic region, and a downfield quartet $(\delta 2.31, J=6.2 \mathrm{~Hz}, 1 \mathrm{H})$ indicated a pentamethylcyclopentadiene $\left(\mathrm{Cp}^{*} \mathrm{H}\right)$ fragment containing a new $\mathrm{C}-\mathrm{H}$ bond (Fig. S4, ESI $\dagger$ ).

An alternative procedure involving protonation of a reduced $\mathrm{Cp}^{*} \mathrm{Rh}$ (bpy) (5) species was also attempted. Reduction of chloride 4 by $\mathrm{NaBH}_{4}$ in $1 \mathrm{M} \mathrm{NaOH}$ led to precipitation of dark purple 5 . Dropwise addition of a dilute solution of $\mathrm{HCl} \cdot \mathrm{Et}_{2} \mathrm{O}$ to an ethereal solution of 5 produced a $\mathrm{Cp}^{*} \mathrm{H}$-containing product similar to the one described above.

Crystals suitable for X-ray diffraction were prepared by vapour diffusion of a solution of the $\mathrm{Cp}^{*} \mathrm{H}$ complex in DCM 


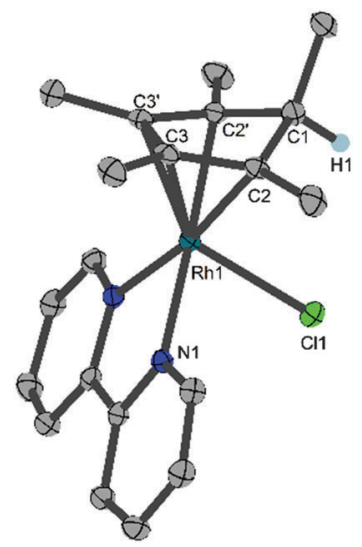

Fig. 1 Structural representation of 1 with ellipsoids drawn at $50 \%$ of probability level (a mirror plane bisects the bpy ligand). $\mathrm{A} \mathrm{CH}_{2} \mathrm{Cl}_{2}$ solvent molecule and hydrogens except $\mathrm{H} 1$ are omitted for clarity. Selected distances (Å) and angles (deg): C1-C2 1.517(2), C2-C3 1.440(3), C3-C3' 1.430(4), Rh1-N1 2.1157(15), Rh1-Cl1 2.5440(6), C2'-C1-C2-C3 31.9(2).

with pentane. The resulting molecular structure revealed the product to be $\left(\mathrm{Cp}^{*} \mathrm{H}\right) \mathrm{Rh}(\mathrm{bpy})(\mathrm{Cl})(\mathbf{1})$, a $\mathrm{Rh}(\mathrm{I})$ complex containing a $\eta^{4}$-pentamethylcyclopentadiene ligand with the new $\mathrm{C}-\mathrm{H}$ bond endo with respect to the metal centre (Fig. 1). The long C1-C2 distance $(1.517(2) \AA)$ compared to the short C2-C3 $(1.440(3) \AA)$ distance confirms that the species is a diene. In contrast, the crystal structure of $\mathrm{Cp}{ }^{*} \mathrm{Rh}(\mathrm{I})$ complex $\mathbf{5}$ shows only a 0.034 A difference amongst the cyclopentadienyl C-C bonds. ${ }^{9}$ Aromaticity has clearly been broken with a C2'-C1-C2-C3 torsional angle of $31.9(2)^{\circ}$ compared to $3.42^{\circ}$ in 5 . The bromide analogue $\left(\mathrm{Cp}^{*} \mathrm{H}\right) \mathrm{Rh}(\mathrm{bpy})(\mathrm{Br})$ was isolated by Winkler, Gray and Blakemore during the preparation of this manuscript and is being investigated as a possible intermediate in $\mathrm{H}_{2}$ evolution in acetonitrile. $^{10}$

The structure of complex $\mathbf{1}$ yields clues about the probable mechanism of its formation. The endo orientation of the hydride is consistent with $\mathrm{C}-\mathrm{H}$ bond-forming reductive elimination of $\mathrm{Cp}^{*}$ and a $\mathrm{Rh}-\mathrm{H}$. Reductive elimination of $\mathrm{Cp}^{*}$ with hydride ligands has been observed from $\mathrm{Rh}$ and Ir metal hydrides with dissociation of the free diene, ${ }^{11}$ and $\mathrm{Cp}^{*} \mathrm{Rh}\left(\mathrm{Cp}^{*} \mathrm{H}\right)$ has been prepared. ${ }^{12}$ As shown in Scheme 2, a Rh hydride intermediate is also consistent with the observation that the $\mathrm{Cp}^{*} \mathrm{H}$ product is formed both by hydride transfer from formate and by protonation of 5.

The intermediacy of a metal hydride was probed by low temperature NMR experiments. Indeed, protonation of $\mathbf{5}$ with $\mathrm{HCl}$ at $233 \mathrm{~K}$ allowed the observation of a $\mathrm{Rh}-\mathrm{H}$ resonance by ${ }^{1} \mathrm{H}$ NMR in a pre-cooled probe $\left(\delta-9.60, J_{\mathrm{RhH}}=19.9 \mathrm{~Hz}\right.$, Fig. S5, ESI $\dagger$ ), which converted to diene 1 upon warming.

Density functional theory (DFT) calculations are consistent with a Rh hydride intermediate that is unstable towards $\mathrm{C}-\mathrm{H}$ reductive elimination. As illustrated in Scheme 3, reductive elimination of the $\mathrm{Rh}$ hydride to form the $\mathrm{Cp}^{*} \mathrm{H}$ complex is favourable by $-4.1 \mathrm{kcal} \mathrm{mol}^{-1}$. In contrast, the Ir analogue $\left[\mathrm{Cp}^{*} \operatorname{Ir}(\mathrm{bpy})(\mathrm{H})\right]^{+}$, which has been isolated and structurally characterized, ${ }^{8}$ is predicted to be unfavourable to $\mathrm{Cp}^{*} \mathrm{H}$ elimination by $8.1 \mathrm{kcal} \mathrm{mol}^{-1}$. Interestingly, the only prior report of a

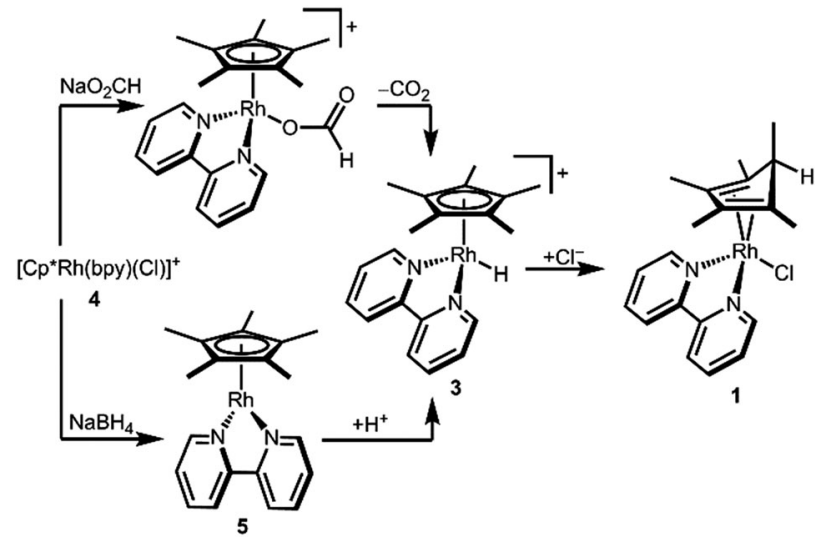

Scheme 2 Alternative routes to diene 1.

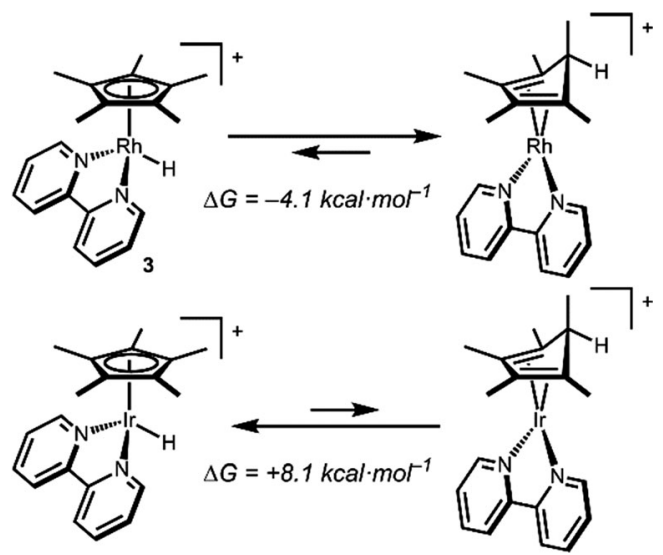

Scheme 3 Free energies for reductive elimination from $C p * M-H(M=R h$, Ir) by DFT.

similar bpy-supported $\mathrm{Rh}$ hydride complex is the methylsubstituted complex $\left[\mathrm{Cp}^{*} \mathrm{Rh}\left(6,6^{\prime}-\mathrm{Me}-\mathrm{bpy}\right)(\mathrm{H})\right]^{+}$, which features steric bulk that might influence this equilibrium. ${ }^{13}$

The apparent instability of the $\mathrm{Rh}$ hydride intermediate with respect to reductive elimination raises questions about how $\mathrm{Cp}^{*} \mathrm{Rh}$-based catalysts mediate hydride transfer reactions. Diene 1 could undergo hydride transfer indirectly via a Rh-H intermediate or via a C-H bond-breaking direct hydride transfer. The latter mechanism illustrates the similarity between diene $\mathbf{1}$ and a variety of transition metal complexes ligated by organic hydride donors and acceptors ${ }^{14}$ and non-innocent ligand backbones capable of de-aromatization. ${ }^{15}$

To better understand complex 2 , we sought to measure the hydricity and establish hydride transfer reactivity. We focused on the closely related complex $\left[\left(\mathrm{Cp}^{*} \mathrm{H}\right) \mathrm{Rh}\left(4,4^{\prime}-\mathrm{COO}-\mathrm{bpy}\right)\right]^{-}$ $\left(\mathbf{1}_{\text {Coo }}\right)$ due to its favourable solubility profile in water. ${ }^{16}$ For Ir-H complexes, carboxylate substitution has a very minor impact on hydricity, ${ }^{6}$ and with the additional distance to the substitution site, the impact on hydricity is expected to be similarly minor for $\left(\mathrm{Cp}^{*} \mathrm{H}\right) \mathrm{Rh}$ complexes.

The hydricity (eqn (5)) was established by determining the $\mathrm{p} K_{\mathrm{a}}$ of $\mathbf{1}_{\mathbf{C o O}}$ (eqn (1)), the reduction potential of [Cp* $\mathrm{Rh}(\mathrm{bpy}-$ $\mathrm{COO})(\mathrm{OH})]^{-}$(eqn (2)) and the $\mathrm{p} K_{\mathrm{a}}$ of the $\mathrm{Rh}(\mathrm{III})$ aquo complex 
$\mathrm{Cp}^{*} \mathrm{Rh}(\mathrm{bpy}-\mathrm{COO})\left(\mathrm{OH}_{2}\right)\left(\mathbf{2}_{\mathbf{C O o}}\right.$; eqn (3)). Combining these experimental values with the free energy of $2 \mathrm{e}^{-}$proton reduction (eqn (4) $)^{17}$ provides $\Delta G_{\mathrm{H}^{-}}^{\circ}\left(\mathrm{OH}_{2}\right)$, the effective hydricity with the formation of an aquated product, according to eqn (6).

$$
\begin{gathered}
\mathbf{1}_{\mathbf{C O O}} \leftrightarrows \mathbf{5}_{\mathbf{C O O}}+\mathrm{H}^{+} \\
\mathbf{5}_{\mathbf{C O O}}+\mathrm{OH}^{-} \leftrightarrows\left[\mathrm{Cp}^{*} \mathrm{Rh}(\mathrm{bpy}-\mathrm{COO})(\mathrm{OH})\right]^{-}+2 \mathrm{e}^{-} \\
{\left[\mathrm{Cp}^{*} \mathrm{Rh}(\mathrm{bpy}-\mathrm{COO})(\mathrm{OH})\right]^{-}+\mathrm{H}^{+} \leftrightarrows \mathbf{2}_{\mathbf{C O O}}} \\
\mathrm{H}^{+}+2 \mathrm{e}^{-} \leftrightarrows \mathrm{H}^{-} \\
\mathbf{1}_{\mathbf{C O O}}+\mathrm{H}_{2} \mathrm{O} \leftrightarrows \mathbf{2}_{\mathbf{C O O}}+\mathrm{H}^{-} \\
\Delta G_{\mathrm{H}^{-}}^{\circ}\left(\mathrm{OH}_{2}\right)=(1.364) \mathrm{p} K_{\mathrm{a}(1)}-(-46.12) E^{\circ}-(1.364) \mathrm{p} K_{\mathrm{a}(3)} \\
+34.2 \mathrm{kcal} \mathrm{mol}^{-1}
\end{gathered}
$$

The reduction potential was measured by cyclic voltammetry (CV) in aqueous phosphate electrolyte. Above $\mathrm{pH} 9$, the $2 \mathrm{e}^{-}$ reduction of $\left[\mathrm{Cp}^{*} \mathrm{Rh}(\text { bpy-COO })(\mathrm{OH})\right]^{-}$to $\left[\mathrm{Cp}^{*} \mathrm{Rh}(\mathrm{bpy}-\mathrm{COO})\right]^{2-}$ $\left(5_{\mathbf{C O O}}\right)$ is quasi-reversible $\left(\Delta E_{\mathrm{p}}=30-80 \mathrm{mV}\right.$ in the $\mathrm{pH}$ range $)$ and $E_{1 / 2}$ shifts cathodically by $24.6 \mathrm{mV}$ per $\mathrm{pH}$ unit, close to the ideal $29.5 \mathrm{mV}$ per $\mathrm{pH}$ unit shift of a $1 \mathrm{OH}^{-} / 2 \mathrm{e}^{-}$process (Fig. S7, ESI $\dagger$ ). Extrapolating this trend to $\mathrm{pH} 0$ (the standard state in eqn (1)-(5)) provides the formal potential, $E^{\circ}=-0.25 \mathrm{~V}$, for the reduction of the hydroxide complex.

To confirm the products of electrochemical reduction, controlled potential electrolysis (CPE) of $\left[\mathrm{Cp}^{*} \mathrm{Rh}(\mathrm{bpy}-\mathrm{COO})(\mathrm{OH})\right]^{-}$ was performed under basic conditions. CPE resulted in a midnight blue solution of $5_{\text {COO }}$ after passing $2 \mathrm{e}^{-}$per $\mathrm{Rh}$ of charge. Upon addition of $\mathrm{pD} 70.1 \mathrm{M}$ sodium phosphate buffer, the blue solution turned red and ${ }^{1} \mathrm{H}$ NMR spectroscopy confirmed formation of $\mathbf{1}_{\mathbf{C O O}}$, as indicated by the characteristic $6: 6: 3$ pattern of the $\mathrm{Cp}^{*}$ methyl resonances.

Diene $\mathbf{1}_{\mathbf{C O O}}$ has $\mathrm{p} K_{\mathrm{a}}<10$ based on a spectrophotometric titration adding acid to an aqueous solution of $\mathbf{5}_{\mathbf{C O O}}$ (Fig. S9, ESI $\dagger$ ). The relative instability of these Rh species (vide infra) led us to carry out a complementary electrochemical titration by monitoring the growth of the oxidation of $\mathbf{5}_{\mathbf{C O O}}$ by $\mathrm{CV}$ as a function of solution $\mathrm{pH}$, providing $\mathrm{p} K_{\mathrm{a}}>8$ (Fig. S10, ESI $\dagger$ ). Each method provides a limiting value (see ESI $\dagger$ figure captions), and we, therefore, estimate that $\mathbf{1}_{\mathbf{C O O}}$ has $\mathrm{p} K_{\mathrm{a}}=9 \pm 1$.

The $\mathrm{Rh}$ (III) species exists as the aquo $\mathrm{Cp}{ }^{*} \mathrm{Rh}(\mathrm{bpy}-\mathrm{COO})\left(\mathrm{OH}_{2}\right)$ $\left(2_{\mathrm{Coo}}\right)$, not the hydroxo complex, under the neutral, aqueous conditions of most catalysis. ${ }^{5 a}$ Incorporation of the $\mathrm{p} K_{\mathrm{a}}$ of the aquo complex ( 8.8 by spectrophotometric titration) accounts for this protonation state.

Based on the experimentally determined $E^{\circ}$ and $\mathrm{p} K_{\mathrm{a}}$ values, eqn (6) provides the aqueous hydricity of $\left[\left(\mathrm{Cp}^{*} \mathrm{H}\right) \mathrm{Rh}(\mathrm{bpy}-\mathrm{COO})\right]^{-}$ to form aquo $2_{\mathbf{C O O}}: \Delta G_{\mathrm{H}^{-}}^{\circ}\left(\mathrm{OH}_{2}\right)=23 \pm 2 \mathrm{kcal} \mathrm{mol}^{-1}$.

Hydride transfer to complex $\mathbf{2}_{\text {Coo }}$ from species with $\Delta G_{\mathrm{H}^{-}}^{\circ}<23 \mathrm{kcal} \mathrm{mol}^{-1}$ is expected to be favourable, and hydride transfer to unsubstituted 2 is expected to proceed with similar driving forces. As expected, $\left[\left(\mathrm{C}_{6} \mathrm{Me}_{6}\right) \mathrm{Ru}(\mathrm{bpy})(\mathrm{H})\right]^{+}\left(\Delta G_{\mathrm{H}^{-}}^{\circ}(\mathrm{Cl})=\right.$ $\left.19.4 \pm 1 \mathrm{kcal} \mathrm{mol}^{-1}\right)^{6}$ reacts with chloride $4\left(\mathrm{Cl}^{-}\right.$is displaced in

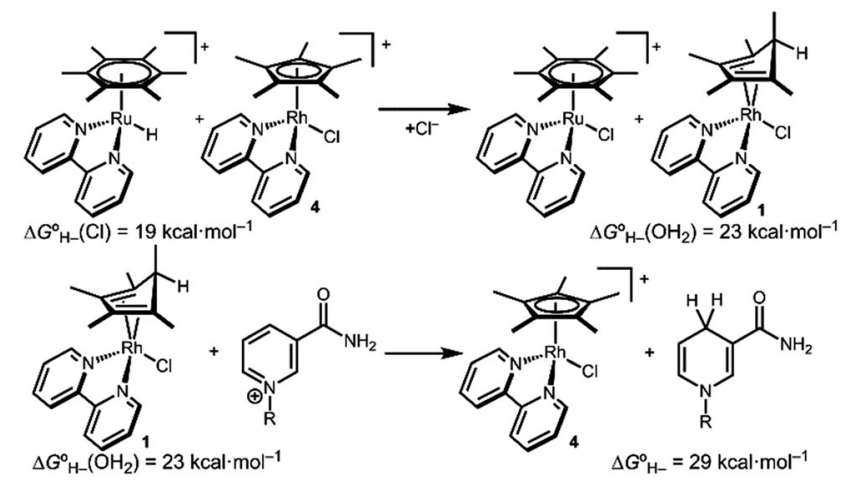

Scheme 4 Selected hydride transfer reactions.

water $\left.^{5 a}\right)$ to produce the corresponding hydride transfer product 1 (Scheme 4). The product slowly decomposed, preventing the system from reaching equilibrium. Transfer does not occur from weaker hydride sources: combining $\left[\mathrm{Cp}^{*} \operatorname{Ir}(\mathrm{bpy}-\mathrm{COO})(\mathrm{H})\right]^{-}$ $\left(\Delta G_{\mathrm{H}^{-}}^{\circ}(\mathrm{Cl})=27.6 \pm 1 \mathrm{kcal} \mathrm{mol}^{-1}\right)^{6}$ with 4 results in no reaction. In accord with the hydricity values, in the reverse reaction diene 1 reacted completely with $\left[\mathrm{Cp}^{*} \operatorname{Ir}(\mathrm{bpy}-\mathrm{COO})(\mathrm{Cl})\right]^{-}$to form $\left[\mathrm{Cp}^{*} \operatorname{Ir}(\mathrm{bpy}-\mathrm{COO})(\mathrm{H})\right]^{-}$.

After establishing the viability of diene complex $\mathbf{1}$ in hydride transfer reactions with transition metal complexes, we turned our attention to hydride transfer involving $\mathrm{NAD}^{+}$. The hydricity of $1,4-\mathrm{NADH}$ is approximately $29 \mathrm{kcal} \mathrm{mol}^{-1}$ (see ESI $\dagger$ ), ${ }^{18}$ so the $\mathrm{Rh}$ diene complex 1 should be sufficiently hydridic to reduce $\mathrm{NAD}^{+}$. A red solution of isolated 1 quickly turned yellow on addition of $\mathrm{NAD}^{+} .{ }^{1} \mathrm{H}$ NMR spectroscopy confirmed consumption of 1 and selective production of 1,4-NADH within 15 minutes.

Finally, we assessed the viability of diene species $\mathbf{1}$ as an intermediate on the $\mathrm{NAD}^{+}$reduction cycle by mimicking various chemical and electrochemical catalytic conditions typically employed. Reduction of 4 in $\mathrm{D}_{2} \mathrm{O}$ with 10 eq. formate forms the red hydride migrated complex 1 immediately, as judged by the appearance of a $6: 6: 3$ pattern in the $\mathrm{Cp}^{*}$ region. The same species is also formed upon reduction of chloride 4 at $-0.64 \mathrm{~V}$ vs. NHE in $\mathrm{pD} 70.1 \mathrm{M}$ phosphate buffer. Even treatment of aquo 2 with $1 \mathrm{~atm} \mathrm{H}_{2}$ in $\mathrm{pD} 70.1 \mathrm{M}$ phosphate buffer produced a diene complex.

The presence of $\mathbf{1}$ under catalytically relevant conditions indicates that it is a viable intermediate. Complex $\mathbf{1}$ is not the only $\mathrm{Rh}$ species in these solutions, however, and this species does not exhibit long term stability under aqueous conditions. Bubbles formed on the walls of NMR tubes containing 1 in neutral aqueous solutions, indicating $\mathrm{H}_{2}$ evolution. The $\mathrm{Cp}^{*}$ methyl protons also scrambled $\mathrm{H}$ for $\mathrm{D}$. Such scrambling has been observed for $\mathrm{Cp}^{*}$ ligands and typically proceeds through a base-assisted mechanism via fulvene intermediates. ${ }^{19} \mathrm{We}$ have also observed the per-deuteration of $\mathrm{Cp}^{*}$ in $\left[\mathrm{Cp}^{*} \operatorname{Ir}(\mathrm{bpy}-\mathrm{COO})(\mathrm{H})\right]^{-}$ by ${ }^{2} \mathrm{H}$ NMR and MS, but deuteration in the Ir manifold occurs over the course of weeks, while deuteration in the Rh manifold occurs over the course of hours. Broad resonances shifted slightly upfield of each proteo $\mathrm{Cp}^{*} \mathrm{H}$ signal appear quickly before the signals slowly disappear altogether. 


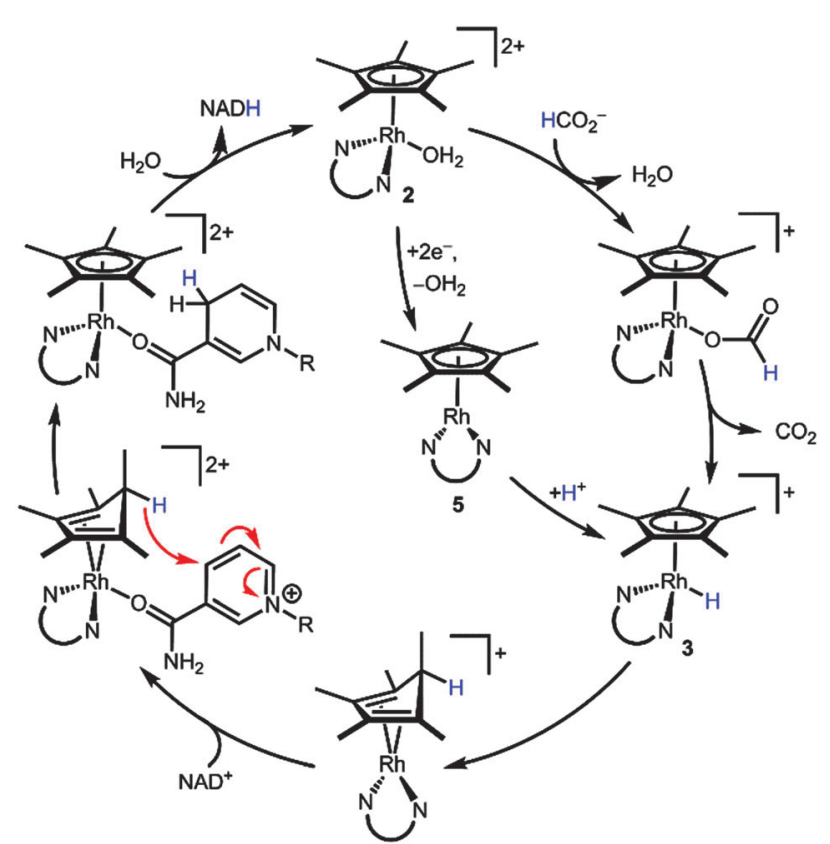

Scheme 5 Proposed mechanism for the reduction of $\mathrm{NAD}^{+}$through a $\left[\left(\mathrm{Cp}{ }^{*} \mathrm{H}\right) \mathrm{Rh}(\mathrm{bpy})\right]^{+}$intermediate. $\mathrm{N} \cup \mathrm{N}$ is bpy.

Scheme 5 combines our new findings with Fish's original mechanistic proposal ${ }^{3}$ to construct an alternative mechanistic hypothesis. Starting from the aquo precatalyst 2 , a $1 \mathrm{H}^{+} / 2 \mathrm{e}^{-}$ reduction (either by a hydride donor, e.g. formate, or through reduced species 5 ) transiently produces metal hydride 3 . Reductive elimination yields a $\left(\mathrm{Cp}^{*} \mathrm{H}\right) \mathrm{Rh}$ moiety. The endo orientation of the proton seems to ideally position the $\mathrm{C}-\mathrm{H}$ bond to deliver hydride to a bound substrate such as $\mathrm{NAD}^{+}$ligating the Rh centre. Following hydride transfer, displacement of NADH by water regenerates the initial state of the catalyst. Several other mechanisms can be envisioned, such as hydride transfer via reversible access to the high energy hydride intermediate 3 . The mechanism in Scheme 5 offers an alternative path for substrate binding without invoking an $\eta^{5}$ - to $\eta^{3}-\mathrm{Cp}^{*}$ ring slip.

We have prepared a pentamethylcyclopentadiene complex of $\mathrm{Rh}$ that is a plausible intermediate in the selective catalytic reduction of $\mathrm{NAD}^{+}$to 1,4-NADH. Hydricity measurements confirm that diene $\mathbf{1}$ is thermodynamically capable of hydride transfer to $\mathrm{NAD}^{+}$. A series of hydride transfer reactions to $\mathrm{NAD}^{+}$and other transition metals are consistent with the hydricity value. This surprising ligand-based hydride transfer reactivity, involving the typically innocent pentamethylcyclopentadienyl ligand, suggests new pathways for $\mathrm{Cp}^{*} \mathrm{Rh}$-catalyzed management of protons and electrons.

The authors gratefully acknowledge funding from NSF Center for Enabling New Technologies through Catalysis (CENTC),
CHE-1205189, the University of North Carolina at Chapel Hill, and the Royster Society of Fellows (C. L. P.). We thank P. S. White for crystallographic support and K. R. Brereton for her assistance with DFT.

\section{Notes and references}

1 (a) J.-M. Fang, C.-H. Lin, C. W. Bradshaw and C.-H. Wong, J. Chem. Soc., Perkin Trans. 1, 1995, 967-978; (b) H. C. Lo and R. H. Fish, Angew. Chem., Int. Ed., 2002, 41, 478-481; (c) H. Zhao and W. A. van der Donk, Curr. Opin. Biotechnol., 2003, 14, 583-589; (d) H. K. Chenault and G. M. Whitesides, Appl. Biochem. Biotechnol., 1987, 14, 147-197.

2 W. A. van der Donk and H. Zhao, Curr. Opin. Biotechnol., 2003, 14, 421-426.

3 H. C. Lo, C. Leiva, O. Buriez, J. B. Kerr, M. M. Olmstead and R. H. Fish, Inorg. Chem., 2001, 40, 6705-6716.

4 (a) T. Ghosh, T. Slanina and B. König, Chem. Sci., 2015, 6, 2027-2034; (b) C. Leiva, H. C. Lo and R. H. Fish, J. Organomet. Chem., 2010, 695, 145-150.

5 (a) U. Kölle and M. Grätzel, Angew. Chem., Int. Ed. Engl., 1987, 26, 567-570; (b) U. Kölle, B.-S. Kang, P. Infelta, P. Comte and M. Grätzel, Chem. Ber., 1989, 122, 1869-1880.

6 C. L. Pitman, K. R. Brereton and A. J. M. Miller, J. Am. Chem. Soc., 2016, 138, 2252-2260.

7 (a) C. Creutz and M. H. Chou, J. Am. Chem. Soc., 2009, 131, 2794-2795; (b) A. Taheri, E. J. Thompson, J. C. Fettinger and L. A. Berben, ACS Catal., 2015, 5, 7140-7151; (c) A. Taheri and L. A. Berben, Inorg. Chem., 2016, 55, 378-385; (d) C. Tsay, B. N. Livesay, S. Ruelas and J. Y. Yang, J. Am. Chem. Soc., 2015, 137, 14114-14121.

8 T. Abura, S. Ogo, Y. Watanabe and S. Fukuzumi, J. Am. Chem. Soc., 2003, 125, 4149-4154.

9 J. D. Blakemore, E. S. Hernandez, W. Sattler, B. M. Hunter, L. M. Henling, B. S. Brunschwig and H. B. Gray, Polyhedron, 2014, 84, 14-18.

10 L. M. A. Aguirre Quintana, S. I. Johnson, S. L. Corona, W. Villatoro, W. A. Goddard III, M. K. Takase, D. G. VanderVelde, J. R. Winkler, H. B. Gray and J. D. Blakemore, submitted.

11 (a) W. D. Jones, V. L. Kuykendall and A. D. Selmeczy, Organometallics, 1991, 10, 1577-1586; (b) A. Pedersen and M. Tilset, Organometallics, 1993, 12, 3064-3068.

12 (a) O. V. Gusev, L. I. Denisovich, M. G. Peterleitner, A. Z. Rubezhov, N. A. Ustynyuk and P. M. Maitlis, J. Organomet. Chem., 1993, 452, 219-222; (b) T. Cadenbach, C. Gemel, R. Schmid and R. A. Fischer, J. Am. Chem. Soc., 2005, 127, 17068-17078.

13 E. Steckhan, S. Herrmann, R. Ruppert, E. Dietz, M. Frede and E. Spika, Organometallics, 1991, 10, 1568-1577.

14 (a) Y. Matsubara, S. E. Hightower, J. Chen, D. C. Grills, D. E. Polyansky, J. T. Muckerman, K. Tanaka and E. Fujita, Chem. Commun., 2014, 50, 728-730; (b) A. McSkimming, M. M. Bhadbhade and S. B. Colbran, Angew. Chem., Int. Ed., 2013, 52, 3411-3416; (c) A. McSkimming and S. B. Colbran, Chem. Soc. Rev., 2013, 42, 5439-5488.

15 J. R. Khusnutdinova and D. Milstein, Angew. Chem., Int. Ed., 2015, 54, 12236-12273.

$161_{\text {Coo }}$ may be ligated by $\mathrm{H}_{2} \mathrm{O}$, but the solvent is assigned unity activity so the thermodynamics are not affected.

17 S. J. Connelly, E. S. Wiedner and A. M. Appel, Dalton Trans., 2015, 44, 5933-5938.

18 (a) J. J. Warren, T. A. Tronic and J. M. Mayer, Chem. Rev., 2010, 110, 6961-7001; (b) F. L. Rodkey, J. Biol. Chem., 1955, 213, 777-787.

19 (a) J. W. Kang and P. M. Maitlis, J. Organomet. Chem., 1971, 30, 127-133; (b) G. Ciancaleoni, S. Bolaño, J. Bravo, M. Peruzzini, L. Gonsalvi and A. Macchioni, Dalton Trans., 2010, 39, 3366-3368. 